\title{
First-generation Ghanaian migrants in the UK; dietary intake, anthropometric indices and nutrition education through the Black churches
}

\author{
J. Adinkrah and D. Bhakta \\ London Metropolitan University, London N7 8DB, UK
}

There is evidence to suggest that African and Afro-Caribbean migrants in developed countries have a higher prevalence of obesity, diabetes and hypertension than the host population ${ }^{(1)}$. Dietary and anthropometric data particularly for first-generation Ghanaian migrants in the UK are limited primarily because of the difficulty of access ${ }^{(2)}$. The majority of first-generation Ghanaian migrants in UK are Christian and attend church regularly ${ }^{(2)}$ and as the church has been used successfully in the USA as a setting to deliver nutrition interventions ${ }^{(3)}$ it was decided to approach the pastors of the UK Black majority churches to allow access to this population to collect dietary and anthropometric data, and then to assess the feasibility of conducting a nutrition education programme targeted specifically for this population.

Five Black majority churches in London agreed to participate in the study and eighty-seven volunteers aged between 18 and 60 years were interviewed face-to-face to complete the semi-quantitative FFQ. The FFQ was developed using data from repeated $24 \mathrm{~h}$ recalls and $7 \mathrm{~d}$ records. A food list was constructed based on the most-commonly-reported foods and portion sizes, and was then field tested, shortened and developed into the final FFQ. Data were also collected for other lifestyle factors, height, weight, waist circumference and waist:hip ratio and percentage body fat was measured using portable bioelectric impedance analysis. Dietary data were analysed using $\mathrm{UK}^{(4)}$ and Ghana (FAK Tayie and A Lartey, unpublished results) food composition tables.

Preliminary validation of the FFQ with multiple $24 \mathrm{~h}$ recalls showed good overall agreement for energy $(r 0.77)$, protein $(r$ 0.54), fat $(r$ 0.56) and carbohydrate $(r$ 0.65). Energy intake was higher in women than men $(8983 \mathrm{~kJ}(2147 \mathrm{kcal}) v .8745 \mathrm{~kJ}(2090 \mathrm{kcal}) ; P<0.05)$ as was fat intake $\left(81.3 \mathrm{~g} v .76 .9 \mathrm{~g}\right.$ respectively; Table). On average, Ghanaian migrant women had a higher BMI than men $\left(27.3 \mathrm{~kg} / \mathrm{m}^{2}\right.$ $\left.v .24 .3 \mathrm{~kg} / \mathrm{m}^{2}\right)$ and a significantly higher percentage body fat $(43 \% v .25 \% ; P<0.05)$. Overall $48 \%$ of the population were overweight or obese, with higher rates of obesity exhibited by females (26\%) than males (18\%). Other studies have shown that obesity is higher among females than males in this population ${ }^{(5)}$. The preliminary findings suggest that this population is at high risk of obesity, and access through the Black majority churches will be an innovative way to educate and promote a healthier diet and lifestyle.

Table. Validation of FFQ with multiple $24 \mathrm{~h}$ recalls

\begin{tabular}{|c|c|c|c|c|c|c|c|c|c|c|}
\hline & \multicolumn{5}{|c|}{ Males (n 32) } & \multicolumn{5}{|c|}{ Females $(n 55)$} \\
\hline & \multicolumn{2}{|c|}{$24 \mathrm{~h}$ recalls } & \multicolumn{2}{|c|}{ FFQ } & \multirow[b]{2}{*}{$r$} & \multicolumn{2}{|c|}{$24 \mathrm{~h}$ recalls } & \multicolumn{2}{|c|}{ FFQ } & \multirow[b]{2}{*}{$r$} \\
\hline & Mean & $\overline{\mathrm{SD}}$ & Mean & $\overline{\mathrm{SD}}$ & & Mean & $\overline{\mathrm{SD}}$ & Mean & $\overline{\mathrm{SD}}$ & \\
\hline Energy $(\mathrm{kJ})$ & 8355 & 958 & 8745 & 946 & $0.79 *$ & 8862 & 732 & 8983 & 686 & $\overline{0.74 *}$ \\
\hline Protein (g) & 58 & 35 & 76 & 18 & $0.40 * *$ & 68 & 25 & 62 & 11 & $0.67 * *$ \\
\hline Fat $(\mathrm{g})$ & 83 & 21 & 77 & 16 & $0.54 *$ & 78 & 13 & 81 & 23 & $0.58 *$ \\
\hline $\mathrm{CHO}(\mathrm{g})$ & 254 & 26 & 273 & 34 & $0.68^{*}$ & 286 & 27 & 292 & 31 & $0.62 *$ \\
\hline
\end{tabular}

CHO, carbohydrate. $* P<0.05, * * P<0.01$.

1. Mennen LI, Jackson M, Sharma S et al. (2001) Public Health Nutr 4, 765-772.

2. Elam G, McMunn A \& Nazroo J (2001) Feasibility Study for Health Surveys among Black African People Living in England. Final Report Implications for the Health Survey for England 2003. Joint Health Survey of University College, London and the National Centre for Social Research. London: Department of Health.

3. Abubakari AR, Lauder W, Agyemang C et al. (2008) Obes Rev 10, 1467-1468.

4. Food Standards Agency (2002) McCance and Widdowson's The Composition of Foods, 6th summary ed. Cambridge: The Royal Society of Chemistry.

5. Abubakari AR, Lauder W, Agyemang C et al. (2008) Obesity Rev 10, 1467-1468. 